\title{
Seismic stability of the restored architectural monument
}

\section{Сейсмостойкость отрестраврированного памятника архитектуры}

\author{
V.N. Alekseenko, \\ O.B. Zhilenko, \\ Crimean Federal University Vernadsky, Simferopol, \\ Crimea, Russia
}

Key words: architectural monument; seismic; authenticity; strengthening; pasted anchor

\author{
Канд. техн. наук, профессор \\ В.Н. Алексеенко, \\ канд. техн. наук, доцент О.Б. Жиленко, \\ Крымский федеральный университет им. \\ В.И. Вернадского, г. Симфрерополь, \\ Республика Крым, Россия
}

Ключевые слова: памятник архитектуры; сейсмический; аутентичность; усиление; вклеенный анкер

\begin{abstract}
The conservation of monument of architecture of XIX century - the Church of St. Archangel Michael in Sevastopol is discussed in the article. The analysis of the results of the survey of the building is developed and recommendations to strengthen the supporting structures of the church are worked out. The use of traditional methods for enhancing structural and seismic reinforcement of buildings with walls of masonry leads to the inevitable loss of the original facade or interior of the temple. To enhance the analysis and design of earthquake resistant walls pasted anchors performed experimental research collaboration adhesive bonding steel anchors in the stone elements from limestone Krymbalsk deposits. The proposed measures to strengthen allow performing repair and restoration work, without breaking the historical reliability of the facades. Comprehensive solutions for strengthening and ensuring of an acceptable level of safe operation in seismic areas are developed.

Аннотация. В статье обсуждается сохранение памятника архитектуры XIX века - церкви Святого Архангела Михаила в Севастополе. Произведён анализ результатов обследования здания, разработаны рекомендации по усилению несущих конструкций церкви Применение традиционных способов усиления несущих конструкций и повышения сейсмостойкости зданий со стенами из каменной кладки приведет к неизбежной утрате изначальных фасадов или внутреннего убранства храма. Для расчета и конструирования, повышающих сейсмостойкость стен, вклеиваемых анкеров выполнено экспериментальное исследование совместной работы клеевого соединения стальных анкеров в каменных элементах из известняков Крымбальского месторождения. Предлагаемые меры по укреплению позволяют выполнять ремонтнореставрационные работы, не нарушая исторической достоверности фасадов. Разработаны комплексные решения для укрепления и обеспечения приемлемого уровня безопасной эксплуатации в сейсмических районах.
\end{abstract}

\section{Historical information}

The Church of St. Michael the Archangel in the city of Sevastopol (Fig. 1) [1] was constructed in 1849 on the initiative of the chief commander of the Black Sea Fleet - Admiral Mikhail Petrovich Lazarev. Author of the project is not exactly known, but it most likely colonel Fonderveyde, creator of the Cathedral of St. Nicholas, St. Michael's Church because it was the Chapel. 


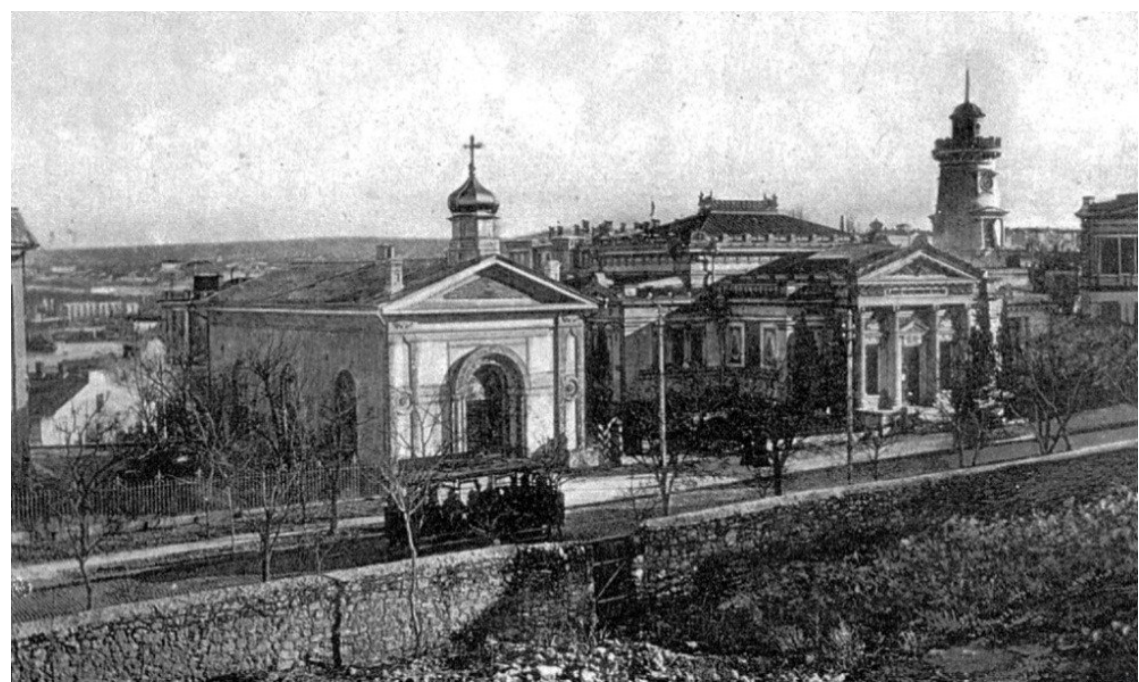

Figure 1. The Church of St. Michael the Archangel in the city of Sevastopol. Historical views

During the 1st defense of Sevastopol garrison church was the main church of the city. Funeral service was conducted there in honour of admirals Kornilov, Istomin, Nakhimov [2].

August 2, 1855 in the church building hit out a bomb, which made it great destruction. The building was restored in 1857 at the expense of the contractor Ivan Krasil'nikov. In 1889 the church became the regimental church of the 50th Regiment Bialystok Infantry.

In the 1920s, in the building there was the Reading Room named after the French Communist Marty. From 1931 Home Health Education was situated there. After World War II the building housed a small temple hall of the House of officers of the fleet. Since 1969 the hall number 8 of the Black Sea Fleet Museum is situated here (Fig. 2).

The building is rectangular in plan. Portal is in the form of niches in one another, covered by arches that rest on columns (two on each side) with Byzantine capitals. Archivolt is carved on the left and right of the entrance there are medallions with rosettes. The walls and columns are built up of small masonry blocks from Krymbalsk deposit (Inkerman).

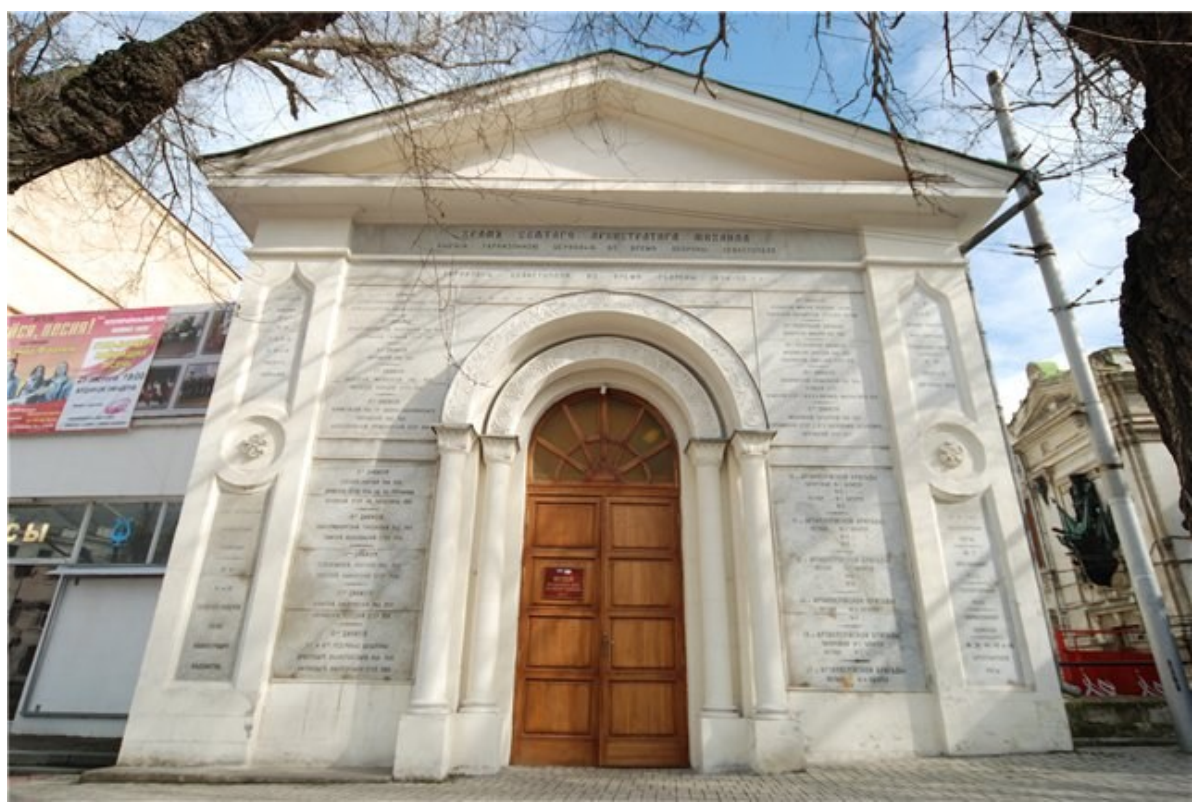

Figure 2. Hall number 8 Black Sea Fleet Museum (Church of St. Michael the Archangel) in Sevastopol is directly adjacent to the House of officers of the Black Sea Fleet. 2012

Two-tier iconostasis with artistic icons made in Odessa by master Dmitri Pashin according drawing, drawn up at the District Engineer's Office by architect Maas. "Interior walls were made by designer Rafael Izellow according to drawing and the direction of the architect Maas with ceiling painted in the colour of the air. Furthermore, it was gilded two rods on the ceiling cornice Fritz "a la grec", with a width of 8 
inches, with the width of the tape 1 inch" (Business Engineering Office of Simferopol distance to restore the Church of St. Michael the Archangel in 1870, No. 22).

\section{Results of the survey}

The building of the hall number 8 Black Sea Fleet Museum of Russian Federation is located not far from the sea in the south-central part of Sevastopol on Lenin street No. 11, on one of the slopes of the central hill of the city [3].

The construction site is located in the climatic region with the following characteristics [4]: weight of snow cover $-82 \mathrm{~kg} / \mathrm{m}^{2}$; to wind pressure $-46 \mathrm{~kg} / \mathrm{m}^{2}$. The depth of soil freezing is $0.8 \mathrm{~m}$. The plot on which the building is located, refers to the area from 8 - point the calculated seismicity map $A[5,6]$.

One-story building with a basement is rectangular in plan with dimensions $20.3 \times 10.4 \mathrm{~m}$. From the eastern facade was attached apse projecting from the plane of the eastern lateral walls $2.2 \mathrm{~m}$. The height of the basement is $2.35 \mathrm{~m}$, height of the first floor $-7.5 \mathrm{~m}$. The height of the interior space of the apse is $6.0 \mathrm{~m}$.

Foundations under the walls are of the tape rubble. The strength of limestone rocks compression corresponds brands 75-100. Fragmentary masonry made of stones stronger brands up to M 300-400. The width of the sole foundation is not less than $1.2 \mathrm{~m}$, which is sufficient for such building. There is no deformation of the building associated with irregular deflections of foundation so the technical status of the bases is satisfactory. It should be noted that the lack of waterproofing basements require particularly careful drainage from the walls of the building during its operation.

Located in the basement boilers serving the adjacent building of the House of Naval Officers and practically does not work, is a serious threat to the monument of architecture of the XIX century in the case of industrial accident or leakage communications. In addition, when you run this equipment in the basement of the building, there are vibration exposure transmitted to the building and reflects negatively on their condition. It is advisable to this energy-intensive and inefficient equipment obsolete sample to be dismantled or brought outside the building of the monument of architecture of XIX century.

Stone columns section $750 \times 750 \mathrm{~mm}$ located in the basement of the building are made of sawed limestone rock M75 are used as intermediate support beams hardwood floor basement. Technical condition is not suitable for further use without amplification. It is necessary to strengthen it by means of outside steel cage of angular steel.

Overlap of basement is made of wooden structures. Excessive deflections of wooden supporting structures overlap led to the beginning of the destruction of parquet flooring. Elements of overlap are susceptible defeat beetle carpenter. There are traces of a fire in the basement of the building which appeared in charring bearing wooden beams. Pairing beams with stone supports are made without any insulating spacers. Technical condition above the basement is defined as not suitable for further use without strengthening. In this connection, it is recommended to limit the service tour groups in the hall of the museum. Taken into account the actual state of the hardwood floor, it does not seem effective to strengthen it. Expedient removal and device of new overlap are used.

The walls of the building are made of stone masonry from Krymbalsk deposit. Compressive strength of the stone reaches the M 75-M 100. Because of the poor state of the roof and no functioning system water drainage from the roof there is damage of the limestone rocks by defrost. Need a local repair of damaged areas using grids and strengthening complex building mortars. In the cornice area of the walls the disclosure of masonry joints is observed. They need to be repaired by injecting masonry strengthening of specific products [7]. The technical condition of the walls is satisfactory.

In order to improve the building seismic resistance it is advisable to strengthen the outer corners of the building hidden by staging pasted anchors of reinforcing steel $\varnothing 12 \mathrm{~A} 500 \mathrm{C}$ length of $800 \mathrm{~mm}$ in mutually perpendicular directions. Be sure to mask their butts embedded indent by fragments of facade stone masonry (Fig. 3). Consolidation work arched bridges three windows of the southern wall (Fig. 4) by steel strip with pasted anchors (performed secretly unchanged appearance of the historic facade). Existing doorway in the south wall facade is converted into the window, according to the original appearance of the building. 


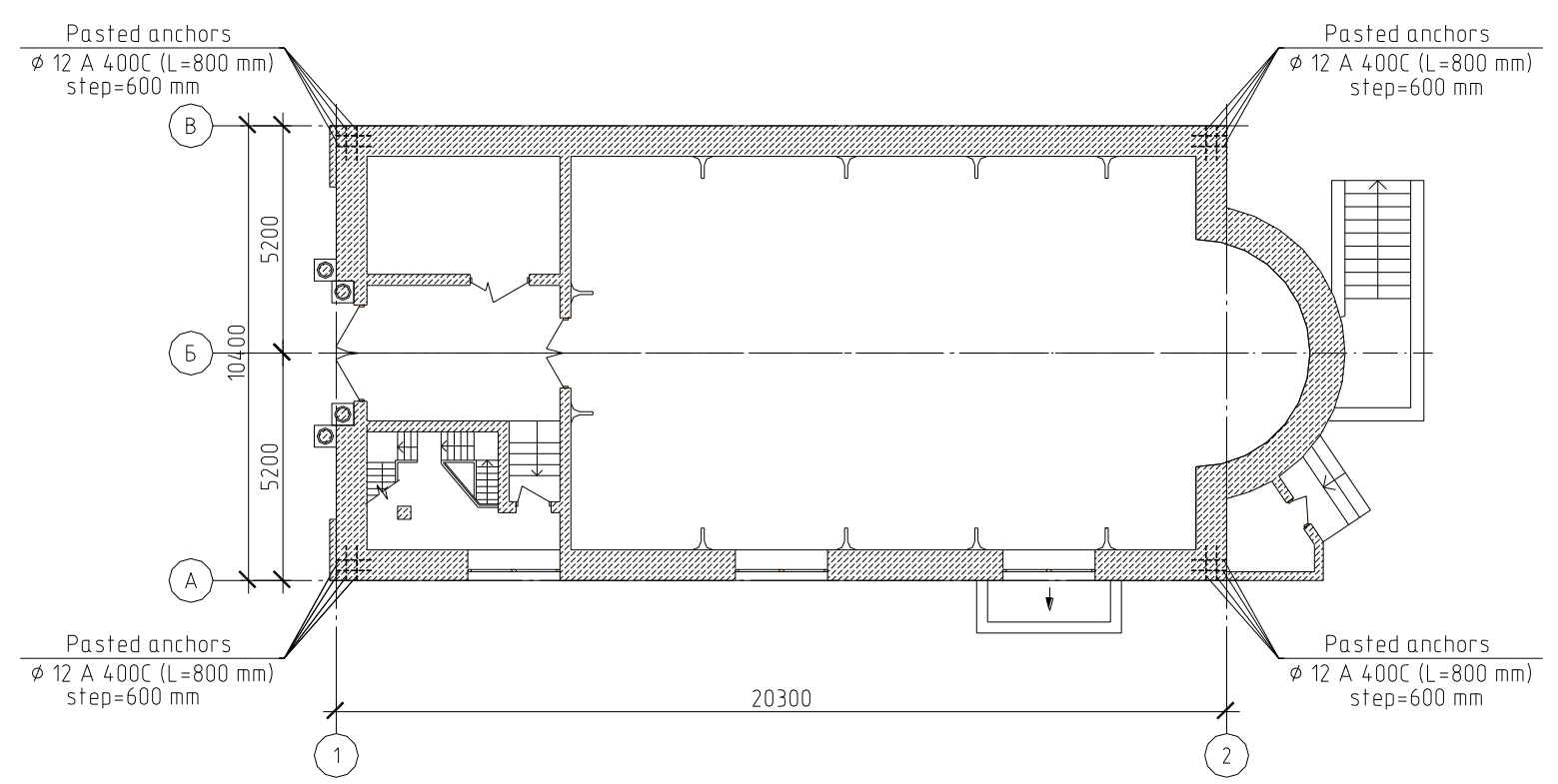

Figure 3. Scheme of strengthening the intersection exterior walls with help of pasted anchors of the Church St. Archangel Michael

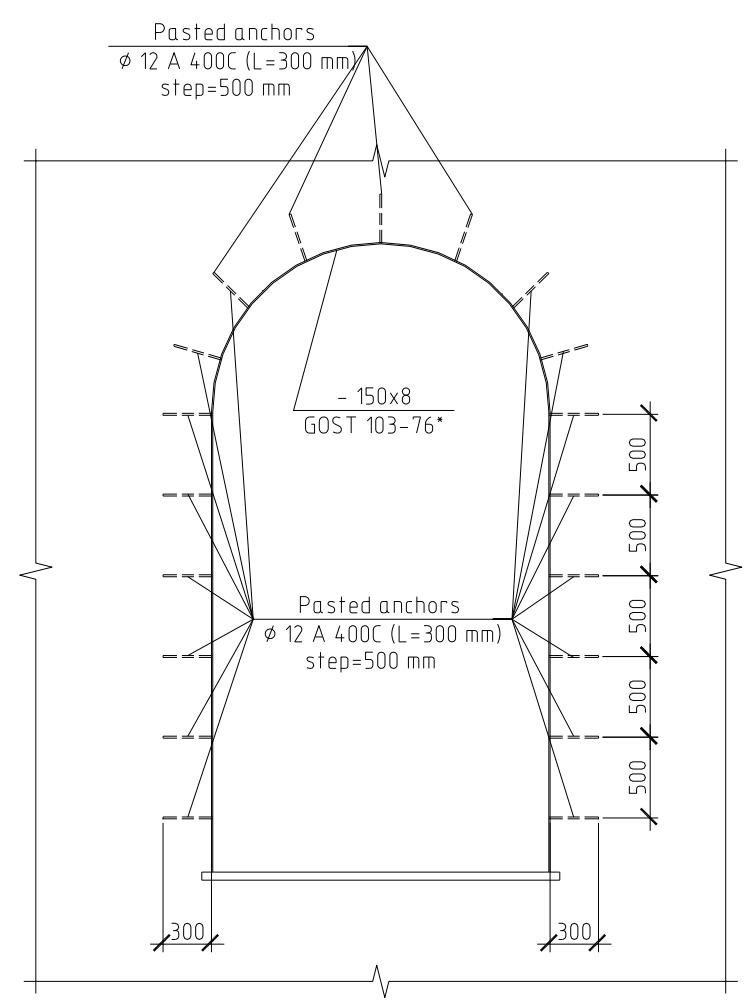

Figure 4. Amplification circuit arched window openings of the southern wall of the building by staging hidden pasted anchors

Reinforced belt section height $150 \mathrm{~mm}$ must be arranged on top of the walls of the main building. it is anchored with glued rods into three levels of height masonry.

The overlap of the first floor was made from metal and wooden trusses on wooden beams using board and plaster. The ceiling of the exhibition hall is damaged with cracks everywhere. The technical condition of the overlap is not suitable for further use without amplification. Given the seismic danger of territory and the simultaneous determination of the potential in the building of a large number of people, it is advisable to replace the heavy wooden ceiling on the modern lightweight suspension systems with efficient light insulation.

On the inner surface of the north wall there is a number of cracks in the stucco layer. All of these areas must be free from loose elements and repaired with the use of reinforcing mesh.

Alekseenko V.N., Zhilenko O.B. Seismic stability of the restored architectural monument. Magazine of Civil 
The roof is made with the use of steel and wooden trusses. Steel trusses are in satisfactory condition. Two wooden trusses are in poor condition; need to replace them with new - metal.

Wooden elements of the roof are subject to constant local leakage and are technically able not suitable for further use. Bearing wooden elements on masonry gables are made without their fix. When you replace sections of the roof it is necessary to arrange the concrete belt height of $150 \mathrm{~mm}$ with the statement pasted into the body of masonry anchors and equipment issues for secure pairing with the elements of the roof.

Bolting suspensions longitudinal joists of exposition hall corrode. Revision of all elements of the compounds is needed when replacing the elements of overlap.

It is necessary to set new metal girders instead of the dismantled wooden trusses and near gables. It is necessary to arrange vertical connections on farms, as well as the necessary horizontal linkages to the lower and upper chord. You need to enable gables through embedded parts in reinforced concrete (arranged) belt in the overall spatial zones of the new system load-bearing structures of the roof. Roofing replaced with new unit system water drainage from the roof, including the roof of the apse.

Dome is recommended to restore the original version of the dome at the western front wall as shown in Figure 1. Supporting the dome to implement the newly arranged by metal girders. Dome must be performed with metal-plating carcass of vertical walls with light modern materials.

\section{The results of calculation}

Spatial settlement building is made taking into account the recommended device of metal roof trusses connected by a common system with concrete belts on top of the walls (Fig. 5). Characteristics of materials adopted in accordance with the results of the survey. In the load on the farm is considered advisable to reconstruct the dome of a metal frame, the vertical part of which is trimmed with light facade materials.

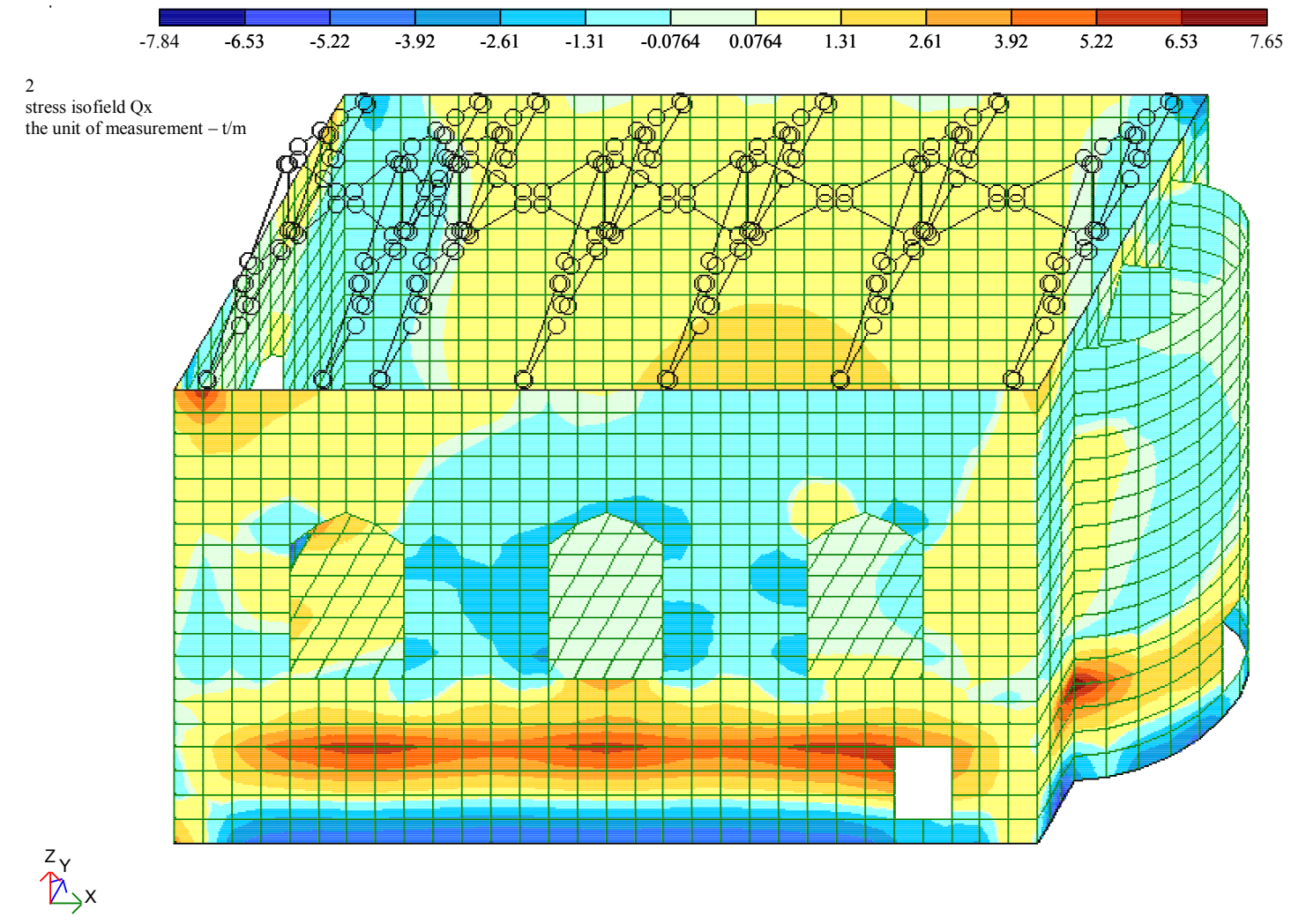

Алексеенко В.Н., Жиленко О.Б. Сейсмостойкость отрестраврированного памятника архитектуры // Инженерно-строительный журнал. 2016. № 7(67). С. 31-38. 


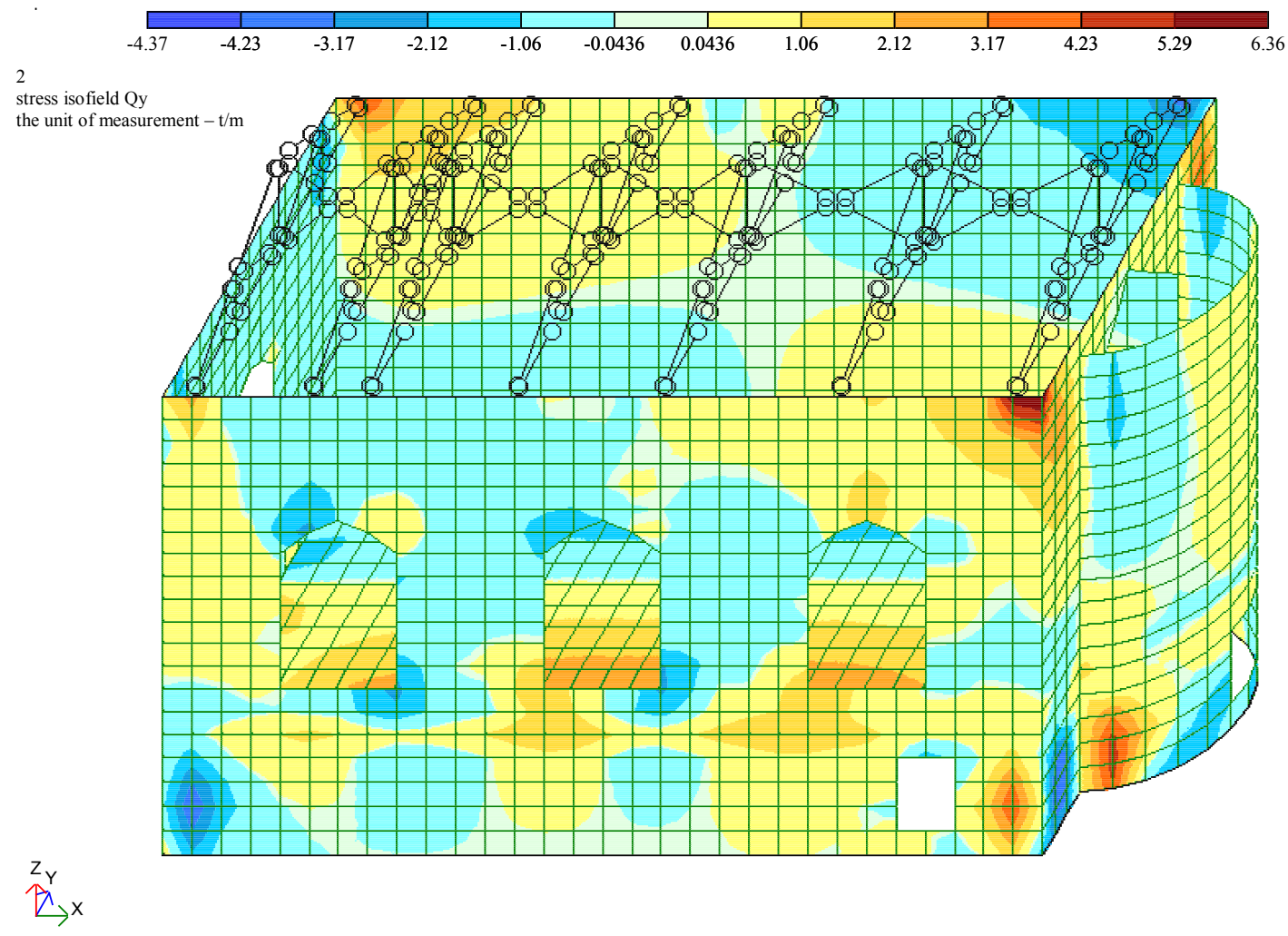

Figure 5. The contour plots of the critical types of stresses in the walls of the building

Existing metal girders may be allowed to continue operating without amplification. Their carrying capacity is sufficient for the perception of the newly arranged the roof with the new sheet metal ceilings of gypsum boards with effective easy insulation.

It is recommended to restore the historical authenticity of the building with three chimneys on the roof, which should be used for ventilation. Heating and ventilation of the building it is recommended to carry out the forced injection through the use of ventilation ducts. Air heating system combined with ventilation to provide a uniform temperature throughout the volume of the serviced apartments [8].

\section{Conclusions}

1. Supporting structures do not meet modern requirements for seismic stability of buildings $[5,6,9-14]$. Hardwood floor basement is in technical condition, not fit for further use. The absence of concrete vertical elements strengthening masonry walls and seismic belts makes use of the building for the mass people stay in the liturgy is very problematic.

2. The use of traditional methods for enhancing structural and seismic reinforcement of buildings [15-19] with walls of masonry lead [20] to the inevitable loss of the original facade or interior of the temple.

3. Proposed by the authors [21-23] the hidden designs of reinforcement of bearing masonry structures glued installation of anchors, opening up new opportunities preserve the authenticity of the Church of St. Michael the Archangel in the city of Sevastopol.

4. To enhance the analysis and design of earthquake resistant walls pasted anchors performed experimental research collaboration adhesive bonding steel anchors in the stone elements from limestone Krymbalsk deposits (Inkerman) 1840's. For steel anchors is widely used reinforcing steel $\varnothing 12 \mathrm{~A} 500 \mathrm{C}$ and anchor mixture - Ceresit CX 5. Exhaustion of the bearing capacity of the adhesive joint with a minimum depth of $300 \mathrm{~mm}$ sealing is achieved with loads of 2.5-3.1 ton. With further increase in load is pulling the anchor stone of the sample (size $200 \times 200 \times 400 \mathrm{~mm}$ ) and was accompanied by his split from the main transverse tensile stresses. Split stones occurred at loads greater than $15-20 \%$ load bearing capacity of the exhaustion of the adhesive joint (by limiting the displacement of the anchor relative to an end surface of the stone $-0.4 \mathrm{~mm}$ ).

5. Given the almost complete absence of adhesion stones Krymbalsk deposit (Inkerman) Crimea with lime-sandy and sandy-clay masonry mortar employed in the first half of the nineteenth century, as well as a sufficiently high strength of these stones compression (reaching $75-100 \mathrm{~kg} / \mathrm{cm}^{2}$ ) - Consolidation of masonry anchors hidden most loaded horizontal impact, with a potential earthquake zones of the

Alekseenko V.N., Zhilenko O.B. Seismic stability of the restored architectural monument. Magazine of Civil 
building can increase its seismic resistance preserving the historical aura of the architectural appearance.

\section{References}

1. Polyostrov sokrovish [Treasure peninsula]. [Online]. System requirements: Joint Photographic Experts Group. URL: http://poluostrovkrym.com/dostoprimechatelnosti/svyatyni-kryma/khramarchistratiga-mikhaila-sevastopol.html (date of reference: 20.12.2014). (rus)

2. Litvinova, N.M. Putevoditel. Krym. Pravoslavnyye svyatyni [Travel Guide. Crimea. Orthodox shrines]. Simferopol: Rubin, 2005. 378 p. (rus)

3. Alekseyenko V.N. Tekhnicheskoye zaklyucheniye po rezultatam obsledovaniya nesushchikh konstruktsiy zdaniya zala No. 8 Myzeja Chernomorskogo Flota Rossijskoy Federacii po adresy: g. Sevastopol, yl. Lenina, 11 s razrabotkoy rekomendaciy po kapitalnomy remonty [Technical conclusion on the results of a survey bearing constructions of the building of the hall No 8 Museum of Russian Black Sea Fleet in Sevastopol, Lenin str., 11, with the development of recommendations for overhaul]. Simferopol: OOO "NPP "Yuzhseysmostroy", 2013. 207 p.

4. SP 20.13330.2011. Nagruzki i vozdeystviya [Russian Set of Rules SP 20.13330.2011. Loads and effects]. Moscow: Minregion Rossii, 2011. 81 p. (rus)

5. SP 14.13330.2011. Stroitelstvo v seysmicheskikh rayonakh [Russian Set of Rules SP 14.13330.2011. Building in seismic regions]. Moscow: Minregion Rossii, OAO "TsPP", 2011. 167 p. (rus)

6. $D B N$ V.1.1-12:2006. Stroitelstvo $v$ seysmicheskikh rayonakh Ukrainy [Ukrainian Set of Rules DBN V.1.112:2006. Construction in seismic regions of Ukraine]. Kiev: Ministerstvo stroitel'stva, arhitektury i zhilishhnokommunal'nogo hozjajstva Ukrainy, 2006. 84 p. (ua)

7. Alekseyenko V.N., Zhilenko O.B. Sovremennyy metod usileniya kirpichnykh sten khrama svyatogo Arkhistratiga Mikhaila $v$ g. Sevastopole $s$ sokhraneniyem yego autentichnosti [The modern method of strengthening the brick walls of the temple of St. Archangel Michael in Sevastopol preserving its authenticity]. Mezhdunarodnaja nauchno-prakticheskaja konferencija Nauka, obrazovaniye $i$ eksperimentalnoye proyektirovaniye. Trudy MARHI [Proceedings of international applied science conference "Science, education and experimental design]. Moscow: Izd-vo MARHI, 2013. Pp. 267-268. (rus)

8. Devin A.R. Mikroklimat tserkovnykh zdaniy [Microclimate of church buildings]. Moscow: GosNIIR, 2000. 189 p. (rus)

9. $D B N$ V.1.1.-1-94. Proyektirovaniye i stroitelstvo grazhdanskikh zdaniy iz blokov kamey pilnykh izvestnyakov Krymskikh mestorozhdeniy v seysmicheskikh [Ukrainian Set of Rules DBN V.1.1.-1-94. Design and construction civil buildings of the blocks and cameos saw limestones Crimean deposits in seismic regions]. Kiev: GoskomUkrainy po delam gradostroitelstva, 1995. $40 \mathrm{p}$.

10. Zakon RSFSR ot 15.12.1978 "Ob ohrane $i$ ispol'zovanii pamjatnikov istorii $i$ kul'tury" [RSFSR Law "On the protection and use of historical and cultural monuments]. Vedomosti S'ezda narodnyh deputatov RSFSR i Verhovnogo Soveta RSFSR. 1978. No. 51. $1387 \mathrm{p}$.

11. Federalnyy zakon Rossiyskoy Federatsii ot 25.06.2002 N 73-FZ. "Ob obyektakh kulturnogo naslediya (pamyatnikakh istorii i kultury) narodov Rossiyskoy Federatsii" [Russian Federal law "On the objects of cultural heritage (historical and cultural monuments) of peoples of the Russian Federation"]. Rossijskaja gazeta. 2002. No. 116-117. (rus)

12. Svod restavratsionnykh pravil SRP - 2007. Rekomendatsii po provedeniyu nauchno-issledovatelskikh, izyskatelskikh, proyektnykh i proizvodstvennykh rabot, napravlennykh na sokhraneniye obyektov kulturnogo naslediya (pamyatnikov istorii i kultury) narodov Rossiyskoy Federatsii [Russian Set of Restoration Rules "Recommendations for research, survey, design and production activities aimed at the

\section{Литература}

1. Полуостров сокровищ [Электронный ресурс]. Систем. требования: Joint Photographic Experts Group. URL: http://poluostrov-krym.com/dostoprimechatelnosti/svyatynikryma/khram-archistratiga-mikhaila-sevastopol.html (дата обращения: 20.12.2014).

2. Литвинова Е.М. Путеводитель. Крым. Православные святыни. Симферополь: Рубин, 2005. 378 с.

3. Алексеенко В.Н. Техническое заключение по результатам обследования несущих конструкций здания зала №8 Музея Черноморского Флота Российской Федерации по адресу: г. Севастополь, ул. Ленина, 11 с разработкой рекомендаций по капитальному ремонту. Симферополь: НПП Южсейсмострой, 2012. 207 с.

4. СП 20.13330.2011 Нагрузки и воздействия. М.: Минрегион России. 2011. 81 с.

5. СП 14.13330.2011. Строительство в сейсмических районах. Минрегион России. М.: ОАО "ЦПП", 2011. 167 c.

6. ДБН В.1.1-12:2006. Строительство в сейсмических районах. Киев: Министерство строительства, архитектуры и жилищно-коммунального хозяйства, 2006. 84 c.

7. Алексеенко В.Н., Жиленко О.Б. Современный метод усиления кирпичных стен храма святого Архистратига Михаила в г. Севастополе с сохранением его аутентичности. // Международная научно-практическая конфреренцияю Наука, образование и экспериментальное проектирование.Труды МАРХИ. М.: МАРХИ, 2013. С. 267-268.

8. Девин А.Р. Микроклимат церковных зданий. Москва: ГосНИИР, 2000. 189 с.

9. ДБН В.1.1.-1-94. Проектирование и строительство гражданских зданий из блоков и камней пильных известняков Крымских месторождений в сейсмических районах. Киев: Госком Украины по делам градостроительства, $1995.40 \mathrm{c.}$

10. Закон РСФСР от 15.12.1978 «Об охране и использовании памятников истории и культуры» (в ред. Указов Президиума ВС РСФСР от 18.01.1985 г., Федерального закона от 25.06.2002 N 73-Ф3 / Ведомости Съезда народных депутатов РСФСР и Верховного Совета РСФСР. 1978. № 51. 1387 с.

11. Федеральный закон РФ от 25.06.2002 N 73-ФЗ. "Об объектах культурного наследия (памятниках истории и культуры) народов Российской Федерации" // Российская газета от 29.06.2002. № 116-117.

12. Свод реставрационных правил СРП - 2007. «Рекомендации по проведению научноисследовательских, изыскательских, проектных и производственных работ, направленных на сохранение объектов культурного наследия (памятников истории и культуры) народов Российской Федерации». М.: Министерство культуры Российской феедерации, 2011. 217 c.

13. ДБН В.3.2-1-2004. Реставрационные, консервационные и ремонтные работы на объектах культурного наследия. Киев, 2005. 121 с.

14. Mrdak I., Rakočević M., Žugić L., Usmanov R., Murgul V., Vatin N. Analysis of the influence of dynamic properties of structures on seismic response according to Montenegrin and European regulations // Applied Mechanics and Materials. 2014. Vols. 633-634. Pp. 1069-1076.

15. Sedova V., Gavrilovic P. Repair and seismic strengthening of historic buildings and monuments - our experience // 12th European Conference on Earthquake Engineering, Elsevier Science Lid. 2002. Paper reference № 182. 
preservation of cultural heritage (monuments of history and culture) of the Russian Federation"]. Moscow: Ministerstvo kul'tury Rossijskoj Federacii, 2011. 217 p.

13. $D B N$ V.3.2-1-2004. Restavratsionnyye, konservatsionnyye i remontnyye raboty na obyektakh kulturnogo naslediya [Ukrainian Set of Rules DBN V.3.2-1-2004. Restoration, conservation and repair work on objects of cultural heritage]. Kiev, 2005. 121 p. (ua)

14. Mrdak I., Rakočević M., Žugić L., Usmanov R., Murgul V., Vatin N. Analysis of the influence of dynamic properties of structures on seismic response according to Montenegrin and European regulations. Applied Mechanics and Materials. 2014. Vols. 633-634. Pp. 1069-1076.

15. Sedova V., Gavrilovic P. Repair and seismic strengthening of historic buildings and monuments - our experience. 12th European Conference on Earthquake Engineering, Elsevier Science Lid. 2002. Paper reference No. 182.

16. Lewis M.A. Rehabilitation of unreinforced masonry walls with externally applied fiber reinforced polymers. A thesis submitted to the Faculty of Graduate Studies and Research in partial fulfillment of the requirements for the degree of Master of Science in Structural Engineering. Department of Civil and Environmental Engineering, Edmonton, Alberta. 1998. $117 \mathrm{p}$.

17. Rekomendatsii po usileniyu kamennykh konstruktsiy zdaniy $i$ sooruzheniy [Recommendations for strengthening the stone buildings and structures]. Stroyizdat. Moscow, 1984. 36 p. (rus)

18. Shagin A.L. Effektivnyye sposoby ukrepleniya kamennykh konstruktsiy [Effective ways of strengthening masonry structures]. Mezhvedomstvennyy nauchno-tekhnicheskiy sbornik nauchnykh rabot (Stroitelstvo). 2001. Issue 54, Harkov: NDIBK. Pp. 264-267. (rus)

19. Yoo Ch.H., Lee S.C. Stability of Structures. Principles and Applications. II Title. Butterworth-Heinemann. Burligton, 1957.

20. Zejak D., Vatin N., Murgul V. Analysis of the masonry structure calculation with vertical ring beams according to European Standards. Applied Mechanics and Materials. 2015. Vols. 725-726. Pp. 111-117. (rus)

21. Alekseyenko V.N., Zhilenko O.B. Sposob usileniya prostenkov sten zdaniy [A method of enhancing partitions walls of buildings]. Patent Ukrain no. 71144, 2012. (ua)

22. Alekseyenko V.N., Zhilenko O.B. Sposob povysheniya seysmostoykosti zdaniy [A method of increasing the earthquake resistance of buildings]. Patent Ukrain no. 62243,2011 . (ua)

23. Alekseyenko, V.N., Zhilenko, O.B. Novie tehnologii $v$ obespechenii seysmostoykosti pravoslavnih svjatin $g$. Sevastopolja [New technologies to provide earthquake resistance of Orthodox shrines in Sevastopol]. [Electronic resource]. System Requirements: AdobeAcrobatReader. URL:

http://unistroy.spb.ru/index_2013_15/7_alekseenko_zhilenk o_15.pdf (date of reference: 12.01.2015). (rus)

24. Sokolov V.A. Probabilistic analysis of intermediate floor steel and wooden structures in the old urban development building. Applied Mechanics and Materials. 2014. Vols. 633-634. Pp. 1040-1048.

Vasiliy Alekseenko,

+7(978)7121807; avn108@mail.ru

Oksana Zhilenko,

+7(978)7068977; o.b.zhilenko@mail.ru
16. Lewis M.A. Rehabilitation of unreinforced masonry walls with externally applied fiber reinforced polymers // A thesis submitted to the Faculty of Graduate Studies and Research in partial fulfillment of the requirements for the degree of Master of Science in Structural Engineering. Department of Civil and Environmental Engineering, Edmonton, Alberta, 1998. $117 \mathrm{p}$.

17. Рекомендации по усилению каменных конструкций зданий и сооружений. ЦНИИСК им. Кучеренко. М.: Стройиздат, 1984. 36 с.

18. Шагин А.Л. Эффрективные способы укрепления каменных конструкций // Межведомственный научнотехнический сборник научных работ. Вып. 54. Харьков: Изд-во НДИБК, 2001. С. 264-267.

19. Yoo Ch.H., Lee S.C. Stability of Structures. Principles and Applications. II Title. Butterworth-Heinemann. Burligton, 1957.

20. Zejak D., Vatin N., Murgul V. Analysis of the masonry structure calculation with vertical ring beams according to European Standards. Applied Mechanics and Materials. 2015. Vols. 725-726. Pp. 111-117.

21. Пат. 71144 Украины, МПК Е04 G23/00. Способ усиления простенков стен зданий. Алексеенко В.Н., Жиленко О.Б.; заявитель и патентовладелец НАПКС. - № u201113119; заявл. 07.11.2011; опубл. 10.07.2012. Бюл. №13.

22. Пат. 62243 Украины, МПК Е04 С2/00. Способ повышения сейсмостойкости зданий. Алексеенко В.Н., Жиленко О.Б.; заявитель и патентовладелец НАПКС. № u201014808; заявл. 10.12.2010; опубл. 25.08.2011, Бюл. №16.

23. Алексеенко В.Н., Жиленко О.Б. Новые технологии в обеспечении сейсмостойкости православных святынь г. Севастополя. [Электронный ресурс]. Систем. требования:: AdobeAcrobatReader. URL: http://unistroy.spb.ru/index_2013_15/7_alekseenko_zhilenk o_15.pdf (дата обращения: 12.01.2015).

24. Sokolov V.A. Probabilistic analysis of intermediate floor steel and wooden structures in the old urban development building // Applied Mechanics and Materials. 2014. Vols. 633-634. Pp. 1040-1048.

Василий Николаевич Алексеенко, +7(978)7068977; эл. почта: avn108@mail.ru

Оксана Борисовна Жиленко, +7(978)7068977; эл. почта: o.b.zhilenko@mail.ru 